\title{
APLIKASI KEBIJAKAN UNTUK MENGATASI PERMASALAHAN TATA RUANG DI KECAMATAN JATINANGOR KABUPATEN SUMEDANG
}

\author{
Oleh: \\ Edi Setiawan, Rudi Saprudin Darwis, \& M. Fedryansyah \\ Email:

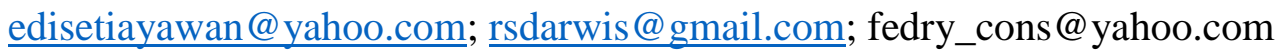

\begin{abstract}
ABSTRAK
Masalah tata ruang di Jatinangor semakin kompleks seiiring berkembangnya zaman dan kebutuhan manusia akan tempat tinggal. Saat ini masalah tersebut sudah berdampak pada masalah banjir yang kerap muncul setiap musim hujan. Untuk mengatasi masalah tersebut pemerintah melalui BAPPEDA Kab. Sumedang membuat suatu rencana program yaitu CAP - RPP (Community Action Plan - Rencana Perumahan dan Permukiman). Dalam program ini terdapat pelibatan masyarakat untuk menyelesaikan masalah tata ruang di Jatinangor sebagai tenaga pendamping penggerak masyarakat lainnya guna memahami bagaimana rencana tata letak bangunan diterapkan dalam membangun perumahan. Melalui artikel ini penulis akan mengkaji program tersebut melalui konsep kebijakan sosial dan pembangunan sosial dimana penulis melihat adanya kontribusi konsep tersebut dilihat dari program tersebut yang memiliki tujuan untuk menyelesaikan masalah sosial dan adanya pelibatan masyarakat yang menurut konsep kesejahteraan sosial dapat ditinjau dari perspektif pembangunan sosial.

Kata Kunci : Tata ruang, Pembangunan sosial, kebijakan sosial
\end{abstract}

\section{PENDAHULUAN}

Jatinangor dahulu merupakan salah satu kawasan yang berada di Kecamatan Cikeruh Kabupaten Sumedang. Penetapan Jatinagor sebagai kota pendidikan tinggi direncanakan sejak tahun 1980 - an sesuai dengan konsep pengembangan wilayah pembangunan (PWP) Bandung Raya. Setelah Jatinangor ditetapkan sebagai kawasan pendidikan tinggi berdasarkan Surat Keputusan Gubernur Kepala Daerah Tingkat I Jawa Barat Nomor : 583/SK-PIK/1989 nama Jatinangor kemudian ditetapkan sebagai kecamatan yang sebelumnya bernama Kecamatan Cikeruh melaui Peraturan Daerah Kabupaten Sumedang Nomor 51 Tahun 2000 tentang Pembentukan Kecamatan serta Keputusan Bupati Sumedang Nomor 6 Tahun 2001 tentang Penetapan Desa dan Kelurahan dalam Wilayah Kecamatan di Kabupaten Sumedang.

Penetapan fungsi Jatinangor sebagai kawasan pendidikan tinggi secara langsung berdampak pada perubahan berbagai aspek kehidupan masyarakat. Perubahan yang terjadi tidak hanya disebabkan oleh sivitas akademika tetapi juga karena perpindahan pelaku kegiatan perdagangan dan jasa untuk memenuhi kebutuhan-kebutuhan yang diperlukan oleh mahasiswa.

Perubahan fisik di Jatinangor terjadi antara tahun 1970 sampai dengan awal tahun 1980-an. Sebagian besar perubahan fisik tersebut terjadi karena adanya perluasan kegiatan perdagangan, pemerintahan dan industri. Dan semakin cepat berkembang dengan dibangunnya 4 (empat) Perguruan Tinggi di kawasan tersebut yaitu : IKOPIN, UNPAD, STPDN dan UNWIM, masing-masing pada 
tahun 1979, 1980, 1981 dan tahun 1986. Kawasan Jatinangor saat ini telah menjadi kota kecil yang terus akan mengalami perkembangan sejalan dengan fungsinya sebagai lokasi pendidikan.

Perkembangan Kawasan Jatinangor pada saat ini semakin tidak terarah, pola pergerakan, transportasi dan kegiatan menjadi lebih hidup dan aktif. Jalan menjadi macet. Lahan beralih fungsi dari peranian/persawahan menjadi permukiman yang tumbuh secara cepat, tidak terkendali bahkan tidak teratur.

Kondisi lingkungan Jatinangor pada saat ini mengalami degradasi akibat pembangunan yang tidak terencana dengan baik, salah satunya adalah tata ruang. Hal ini dapat dilihat dari pembangunan rumah/gedung yang tidak teratur, perumahan yang padat, ketidakteraturan tempat kos, kumuh, jalanan sempit dan rawan macet, penumpukan sampah yang sampai saat ini belum ada penyelesaiannya. Pembukaan lahan yang tidak terkendali dengan dalih pembangunan mengakibatkan Jatinangor menjadi tidak nyaman, rawan banjir, longsor serta udara terasa panas. Pada musim kemarau, Jatinangor mengalami kesulitan air karena hutan sebagai wilayah konservasi telah rusak.

Masalah tata ruang bangunan secara tidak langsung dapat berpengaruh pada timbulnya masalah-masalah sosial seperti banjir. Setiap hujan besar yang mengguyur Jatinangor, beberapa kawasan seperti di Desa Cikeruh selalu tergenang air. Bahkan pada bulan Maret 2014 banjir bandang pernah terjadi dan merusak satu kos-kostan. Selain itu banjir juga mengakibatkan kemacetan panjang di sepanjang jalan raya Jatinangor. Fenomena ini jika dibiarkan tentu akan merugikan banyak orang termasuk mahasiswa. Untuk itu perlu adanya suatu kebijakan sosial khusus mengatur masalah tata letak bangunan di Jatinangor agar masalah sosial seperti banjir dan kemacetan dapat teratasi.

Salah satu program untuk mengatasi masalah tata ruang di Kabupaten Sumedang yang diterapkan juga di Kecamatan Jatinangor adalah program Pendampingan Comunity Action PlanRencana Perumahan Dan Permukiman (CAP-RPP). Program ini muncul atas dasar pemenuhan kebutuhan akan rumah dan kawasan permukiman layak yang semakin sulit terpenuhi, karena berbagai keterbatasan dan hambatan diantaranya; masih belum terlembaganya sistem penyelenggaraan perumahan dan kawasan permukiman yang responsive dengan perkembangan kebutuhan serta layak dari segi penataan sanitasi lingkungan dan ruang terbuka hijau, lalu tidak seimbangnya antara tingginya kebutuhan akan perumahan dan kawasan permukiman yang layak dan terjangkau dengan kemampuan sebagian besar masyarakat di Kabupaten Sumedang dan dengan terbatasnya peran pemerintah dalam pelaksanaan pembangunan perumahan dan permukiman (hanya sebagai fasilitator).

Maka sudah saatnya peran masyarakat didorong, supaya lebih mandiri dan menjadi pelaku utama dalam pembangunan perumahan dan pemukiman yang akan/sudah mereka tempati agar layak dari segi sanitasi serta lingkungannya.

Masyarakat belum siap untuk berperan dalam penyelenggaraan pembangunan di bidang perumahan dan permukiman (belum terinformasikan, belum memahami, dan belum bisa menggali dan mengenali potensi ataupun permasalahan lingkungan tempat tinggalnya) maka dalam hal ini pemerintah Kabupaten Sumedang memberdayakan sekaligus melatih masyarakat untuk jadi tenaga pendamping yang nantinya akan membantu masyarakat disekitarnya mampu menyusun CAP - RPP (Community Action Plan - Rencana Perumahan dan Permukiman) yang secara konsisten dapat dijadikan bahan acuan untuk meningkatkan taraf kehidupannya.

Sehingga diharapkan dengan adanya program CAP-RPP ini masyarakat mampu menyusun suatu rencana tindak lanjut di tingkat komunitas untuk perumahan dan kawasan permukimannya (CAP - RPP), yang secara konsisten dapat dijadikan bahan acuan untuk meningkatkan taraf kehidupannya. Sedangkan keluaran dari progam ini salah satunya adalah terbentuknya tenaga pendamping/penggerak masyarakat (TPM) sebagai tenaga penggerak masyarakat sekaligus sebagai kader yang akan menjembatani antara masyarakat dan pemerintah. 
Dalam aplikasinya kebijakan ini merupakan salah satu bentuk kebijakan sosial dimana peran pekerja sosial dapat diterapkan dan konsep keilmuan kesejahteraan sosial juga dapat menjadi referensi dalam menelaah kebijakan ini.

\section{ISI}

Maksud kegiatan CAP-RPP adalah mempercepat tertatanya perumahan dan kawasan permukiman yang memenuhi standar (rumah layak huni dalam lingkungan sehat, tertata dan terencana), melalui upaya pembangunan dan peningkatan kualitas perumahan dan kawasan permukiman yang berbasis pada keswadayaan masyarakat.

Tujuannya :

1. Membantu masyarakat agar mampu mengenali dan menggali potensi dan permasalahan perumahan dan kawasan permukiman serta lingkungan tempat tinggalnya dan mampu mencari upaya pemecahannya.

2. Membantu masyarakat agar mampu menyusun suatu rencana tindak di tingkat komunitas untuk perumahan dan kawasan permukimannya (CAP - RPP), yang secara konsisten dapat dijadikan bahan acuan untuk meningkatkan taraf kehidupannya.

3. Menyediakan pedoman bagi para pelaku pelaksana pembangunan bidang perumahan dan kawasan permukiman di Kabupaten Sumedang dalam mewujudkan suatu skenario pembangunan dan penataan perumahan dan kawasan permukiman yang disusun secara partisipatif menggali potensi dan identitas kawasan.

Keluaran kegiatan CAP-RPP adalah :

1. Terbentuknya tenaga pendamping/penggerak masyarakat (TPM) sebagai tenaga penggerak masyarakat sekaligus sebagai kader yang akan menjembatani antara masyarakat dan pemerintah.

2. Skenario Penataan perumahan dan kawasan permukiman dalam bentuk CAP-RPP, yang berisikan :

a. Konsep Pembangunan dan Penataan Lingkungan.

b. Matriks Program Lima Tahunan.

3. Dokumen Perencanaan Pembangunan dan Penataan perumahan dan Kawasan permukiman yang disusun mencakup :

a. Gambar Arahan Teknis, untuk keperluan pelaksanaan pembangunan prasarana dan sarana lingkungan tahun pertama serta proyeksi untuk lima tahun yang akan datang.

b. Dokumen Rencana Anggaran Biaya untuk tahun pertama, serta proyeksi untuk lima tahun yang akan datang.

Terbentuknya tenaga pendamping/penggerak masyarakat dalam konteks keilmuan dapat disebut dengan pembangunan sosial. Pembangunan secara umum dapat dikatakan merupakan suatu upaya perubahan untuk menuju keadaan yang lebih baik. Tujuan pembangunan bukan hanya sekedar peningkatan ekonomi masyarakat, seperti yang dikatakan Midgley dalam buku "Social Development - The Developmental Perspective In Social Welfare" mengenai distorted development :

Distorted development exists in societies where economic development has not been accompanied by a concomitant level of social develompent. Distorted development is manifested not only in poverty, deprivation, low health status and inadequate housing but in the exclusion of sections of the population from full participation in development. (Midgley 1995: 4\&5)

Berdasarkan penjelasan diatas, Midgley berpendapat bahwa distorted development adalah suatu kondisi masyarakat dimana terdapat pembangunan ekonomi yang tidak disertai dengan pembangunan di bidang sosial yang memadai. Distorted development tidak hanya terwujud dalam bentuk 
kemiskinan, buruknya kondisi kesehatan masyarakat dan perumahan yang tidak memadai, tetapi distorted development juga dapat dilihat dari tingkat partisipasi masyarakat didalam pembangunan yang rendah.

Proses pembangunan sudah seharusnya menekankan pentingnya peningkatan kapasitas perorangan dan institusional masyarakat yang menjadi sasaran. Sedangkan yang menjadi permasalahan utama dalam distorted development adalah ketidak mampuan dalam menyeimbangkan antara pembangunan ekonomi dengan pembangunan di bidang sosial. Dan untuk mengatasi permasalahan pembangunan ini menurut Midgley, dibutuhkan satu perspektif baru yaitu pembangunan sosial.

As was noted earlier, social development is an approach to promoting people's welfare that is well suited not only to enhancing the quality of life for all citizens but to responding to the problems of distorted development. The conditions of concomitant prosperity and deprivation that characterize so many countries today can best be remedied through an approach that integrates economic and social objectives. (Midgley 1995: 7)

Dalam buku yang sama, Midgley mengungkapkan bahwa pembangunan sosial adalah sebuah pendekatan baru untuk mempromosikan kesejahteraan rakyat. Pendekatan ini tidak hanya tepat untuk meningkatkan kualitas hidup masyarakat tetapi tepat juga untuk menghadapi masalah-masalah yang timbul akibat distorted development.

Kondisi banyak negara saat ini yang mengalami masalah kemakmuran dan kemiskinan dapat diperbaiki melalui pendekatan pembangunan sosial. Karena pendekatan ini adalah pendekatan yang mengintegrasikan tujuan ekonomi dan sosial.

Program CAP - RPP (Community Action Plan - Rencana Perumahan dan Permukiman) ini merupakan salah satu bentuk kebijakan sosial yang diterapkan oleh pemerintah Kabupaten Sumedang dalam rangka mengatur tata ruang mereka. Program ini melibatkan peran aktif masyarakat sebagai tenaga pendamping yang nantinya diharapkan dapat membantu dan bekerja sama dengan pemerintah. Masyarakat yang diharapkan terlibat dalam program ini adalah masyarakat yang dapat menggerakkan ataupun mempengaruhi warga lainnya.

Dalam buku "Social Policy In The Post-Welfare State" kebijakan sosial memiliki pengertian : Social policy, in its essence, is concerned with the regulation of social relationships for the purpose of affirming certain values and interests through the implementation of appropriate means designed to achieve corresponding ends. It has been defined as the 'regulation oh intrasocietal relations and the shaping of the quality of life'. (Gil 1976) (Adam Zamrozik 2001: 38)

Berdasarkan pengertian diatas, kebijakan sosial merujuk pada bentuk keprihatinan terhadap permasalahan-permasalahan sosial untuk tujuan menegaskan nilai-nilai dan kepentingan tertentu melalui penerapan cara yang tepat untuk mencapai tujuan yang sesuai yang telah ditetapkan sebagai regulasi hubungan intra masyarakat dan pembentukan kualitas hidup.

Berkaitan dengan topik yang akan peneliti lakukan, Program CAP - RPP (Community Action Plan - Rencana Perumahan dan Permukiman) di Jatinangor merupakan salah satu bentuk keprihatinan terhadap kondisi tata ruang dan bangunan di Jatinangor. Kondisi tata ruang dan lingkungan di Jatinangor saat ini juga berdampak pada timbulnya permasalahan lain yaitu banjir. Maka dari itu kebijakan CAP-RPP muncul sebagai solusi yang tujuannya telah ditetapkan untuk peningkatan kualitas hidup masyarakat Jatinangor yang terbebas dari masalah tata ruang.

\section{Kesimpulan}

Program CAP - RPP (Community Action Plan - Rencana Perumahan dan Permukiman) di Jatinangor merupakan salah satu bentuk aplikasi konsep pembangunan sosial dan kebijakan sosial 
dimana ada peran peningkatan kapasitas individu dalam konteks pembangunan. Pembekalan terhadap masyarakat mengenai konsep tata ruang diharapkan dapat mengatasi masalah tata ruang di Jatinangor. Dan dengan adanya program ini membuktikan kepada kita bahwa saat ini peran pekerja sosial sangat dibutuhkan dalam penyusunan maupun pelaksanaan pembangunan dan kebijakan sosial. Sebagai bentuk rekomendasi terhadap program ini adalah perlu adanya pengawasan secara formal karena tenaga pendamping yang dipilih adalah masyarakat lokal agar proses pendampingan tetap berada pada jalurnya sehingga program ini dapat berjalan sesuai tujuannya.

\section{Daftar Pustaka}

Midgley, J. (1995). Social Development - The Developmental Perspective In Social Welfare. London: SAGE Publication Inc.

Zamrozik, A. (2009). Social Policy In The Post-Welfare State. australia.

Bapeda Kabupaten Sumedang. (2009). Laporan Akhir Studi Kelayakan Kawasan Jatinangor Sebagai Kawasan Perkotaan, Sumedang 